Frank Möller

Tampere Peace Research Institue. Faculty of Social Science. University of Tampere.

\title{
Witnessing Violence through Photography
}

\section{Global Discourse, published online August 31, 2017}

\begin{abstract}
ABST RACT In this article I think about photojournalists and citizen photographers as, respectively, political and moral witnesses to violence, the one testifying to what it is like to be exposed to extraordinary circumstances, the other showing what it feels like to live in such conditions. The distinction between political and moral witnesses is Avishai Margalit's, developed in his work on remembering and bearing witness to 20th century totalitarian regimes. I re-evaluate photojournalism and citizen photography based on arguments developed outside the established discourse on photojournalism with its emphasis on truth, documentation and verifiability. To explore the potentialities of citizen photography, I think with Margalit, but in a different context, about what it means to be a witness to violence, especially a photographic witness.
\end{abstract}

Focusing on what it feels like to be exposed to extraordinary circumstances and thus emphasizing the affective dimensions of being a witness makes us understand that the truth of the victim does not necessarily reflect objective, empirically measurable and realistically photographable facts. It can be photographed in ways other than those privileged in photojournalism, especially if photographed by citizen photographers who qualify as moral witnesses. Citizen photography is called upon to contribute to a politics of testimony to violence by utilizing its own unique capacities instead of copying photojournalism's dedication to documentation and information. I suggest capitalizing on the combined strengths of citizen photography and professional photojournalism so as to take advantage of all the possibilities photography offers when visualizing and bearing witness to violence.

KEYWORDS Photojournalism, citizen photography, photographic witness, representations of violence, Avishai Margalit 


\section{Witnessing Violence through Photography}

\section{Introduction: opening up debate about citizen photography}

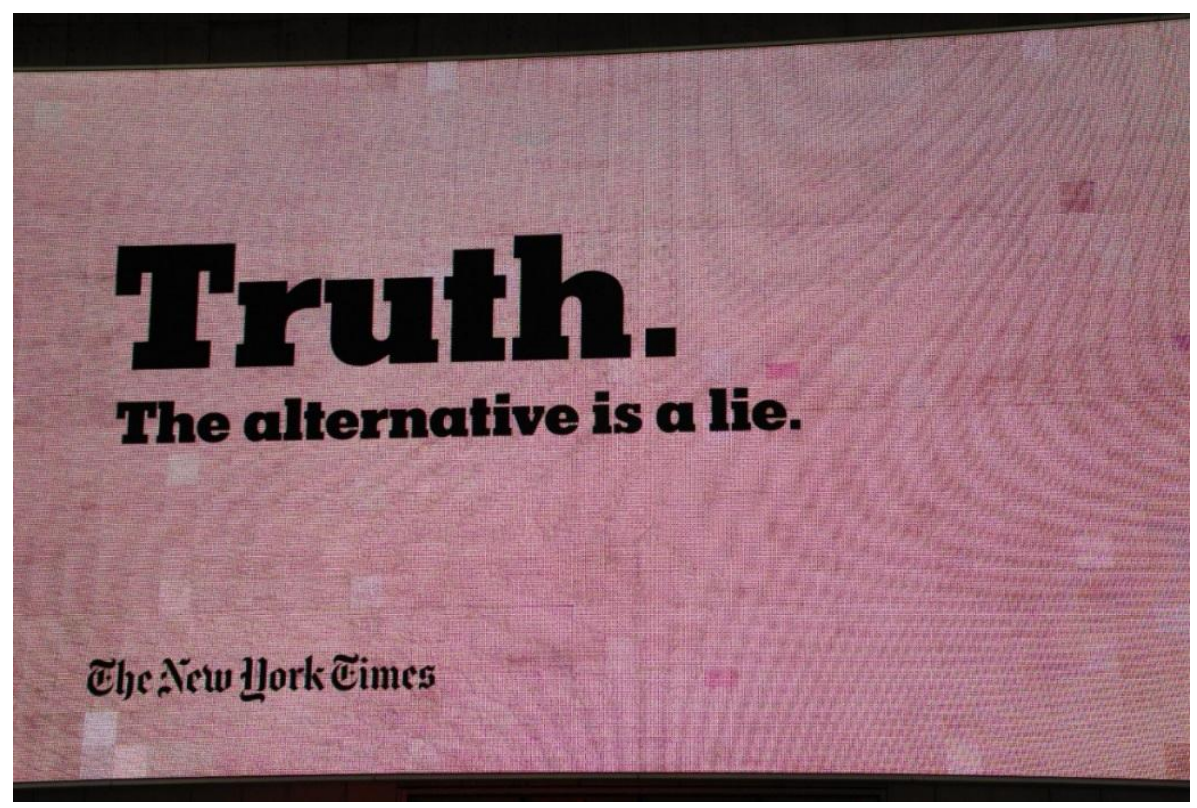

Fig. 1: New Y ork City, February 27, 2017 (photograph: author)

In recent reflections about the ethics of photojournalism, D avid Campbell (2015) suggests that "too often the concept of truth, faith in objectivity, and declarations about reality actually close down debate about what photojournalism and documentary photography are and do." D ebates about truth, objectivity and reality not only close down debate about photojournalism, but also limit photographic practiœ, as photographer Matthew Wylie (2016) observes. Wylie is "interested in how photography can break down the 'rules' that seem to hound it, rather than merely following a tradition." Following a tradition is indeed what photojournalists (are supposed to) do. According to Wylie (2016), "the safe arguments tend to lean towards 'no manipulation'" and this tendency "essentially limits the photographer's gaze to her/ his gear and to the specific 'assignment' on hand." It is therefore hardly surprising that "what the future will literally look like in photojournalism has a lot to do with what the past has already looked like' because 'formative fictions structure future frames" (Gursel 2016, 123). Photojournalists, it seems, deliberately do not take advantage of all the possibilities photography offers. In Ben Curtis's words, if "you're doing fine art photography, you can do what you want. But if your photos are intended to represent the truth, then it's a completely different situation" (as quoted in Morris 2014, 194). In other words, if you are doing photojournalism, you cannot do what you want. 
Emphasis on truth and objectivity does not only obscure photojournalism and documentary photography, as the critical literature associated with such authors as Abigail Solomon-Godeau (2003) and Martha Rosler (2006) has shown, but also citizen photography. However, evaluating citizen photography in light of an (idealized) photojournalistic tradition in terms of verifiability, truth and objectivity is only one possible approach to citizen photography among others just as is advising citizen photographers to work according to the established operating procedures of their professional colleagues (and dismissing their work if it does not seem to respect professional standards). In other words, reducing citizen photography to some kind of photojournalism, committed to photojournalism's governing principles, makes us effectively blind for citizen photography's potentialities beyond photojournalism. Looking at citizen photography inspired by the history of the discursive construction - not necessarily the practice - of photojoumalism with its focus on information and documentation limits our understanding of what citizen photography is and does. ${ }^{1}$ Citizen photography does inform and it does document but it does more than that. The main objective of this article, then, is not a critique of photojournalism and its underlying operating procedures but rather a re-evaluation of citizen photography based on arguments developed outside the discourse on photojournalism. If the "safe arguments" (Wylie) tend to close down debate, then it might indeed be worth the while to employ unsafe arguments so as to open up debate - arguments borrowed from other discourses, arguments that are not (yet) confirmed, through repetition, in photographic discourses to such an extent that they appear natural. As a heuristic device, then, I will engage with the popular, yet undertheorized figure of the photographer as a witness: I will ask what kind of witness photographers are and what it means to witness violence through photography. Following Avishai Margalit's distinction between political and moral witnesses (2004, 147-182), I will provisionally offer a simple typology: I shall regard professional photojournalists as photographers showing "the thing itself" (Roberts 2014) or "a real horror" (Sontag 2003, 42) - be it war, genocide, or other violent conflicts like it is and citizen photographers as photographers showing it like it feels. As photography is constantly developing, concepts can only ever be tentative, necessitating further investigation and differentiation in light of new empirical findings and refined conceptual thinking. ${ }^{2}$

\footnotetext{
1 Stuart Allan's new edited book will shed further light on the relationship between photojournalism and citizen photography (Allan, forthcoming).

2 A note on method: I start by developing analytical concepts or applying existing concepts in order to grasp what I (and others) have observed empirically. As every concept, as 'an idea of a class of objects, a general notion,' reduces complexity, these concepts are subsequently critically interrogated and deconstructed. In a third step, their ingredients are reassembled either to confirm earlier concepts or to alter them. The newly constructed concepts are then exposed to the same procedure, and so on. This process is potentially infinite. Obviously, this article (being conceptual rather than empirical) is concerned only with the first step. Throughout the article, I emphasize that what I am writing about are concepts or ideal-types, constructed for analytical purpose. The resulting concepts may appear somewhat rigid or schematic. The absence from this article of deconstruction -
} 
I will start this article by discussing photojoumalism and citizen photography as separate, yet related genres of image production. As there can be observed a "blurring of genre boundaries" (Patrick 2014, 240) with some photographers moving rather freely from one genre to another, the following discussion should be understood as ideal-typical. ${ }^{3}$ Secondly, I will review the (highly idealized) operating procedures for photojournalists - what I call the myth of photojournalism - as socially and historically constructed in photography discourses. The myth of photojournalism is relevant for a discussion of both photojournalism and citizen photography because it often serves as the standard against which both forms of image production are being evaluated. Thirdly, I will engage with concepts of remembering and bearing witness as developed in the social sciences and think about photography in terms suggested in these concepts, especially in Margalit's work on remembering and bearing witness to 20th century totalitarian regimes. Throughout the paper, rather than ranking photojournalism and citizen photography, I will suggest capitalizing on the combined strengths of citizen photography and professional photojournalism (and other forms of image production, excluded from this article, as well) in order to take advantage of all the possibilities photography offers when visualizing and bearing witness to violence. ${ }^{4}$

\section{Photojoumalism and citizen photography}

I differentiate from one another two types of image-makers - professional photojournalists and citizen photographers - and I do so ideal-typically for analytical purposes disregarding, for example, the "blurring of genre boundaries" (Patrick) referenced above. Although there can be found numerous positions as regards politics, ethics and aesthetics within these genres, for the purpose of this article I will treat each of them largely as a unitary actor. In spite of the seemingly simple production process of a photograph, the photographic "image is not the duplication of a thing" (Rancière 2009, 93). In Susan Sontag's words, the photographic image "cannot be simply a transparency of something that happened" $(2003,46)$ and this is true of both the images produced by professional photographers and those produced by citizen photographers. However, every photographic image claiming to be photojournalistic relies on and appeals to the belief among audiences that what can be seen did, in a way not unrelated to what can be seen in the image, actually happen. In photographer Jerry L.

largely due to the limitations of a single article - implies need for deconstruction to which I would like to invite all readers. The quotation is from The Shorter $0 \mathrm{x}$ ford E nglish D ictionary on H istorical Principles, Vol. I, p. 388.

3 Art photography and digital fabrication and alteration of photographs may also bear witness, not only to the photographer's creativity but also to those features of the world that traditional photography misses or cannot visualize.

${ }^{4}$ As I have argued elsewhere (Möller 2017), visualizing and bearing witness to violence can, in itself, be an act of violence. 
Thompson's words, photographic pictures, as long as they are lens-made, "are inextricably linked to the real world" (2003,3). Perhaps it would be more appropriate to write that every photograph is linked to the real worlds. Thompson's "real world" can be photographed in many different ways; there are, arguably, as many real worlds as there are photographs. Every photograph reflects numerous choices made by the photographer or an editor: photographers decide what to photograph and what not; what to include in the image and what to exclude from it. They decide how to photograph (from what angle, with what lens and so on) what they have decided to photograph; photographers - or editors - select a limited number of images for publication thus influencing what a larger audience can and cannot see (see Sontag 2003, 46). Given digitization and ubiquitous image dissemination on social media, this influence nowadays may not be as strong as it used to be but it still exists, and some conflicts are decidedly under referenced in visual media (Sontag 2003, 37).

Professional photojournalists work on assignment for newspapers, television networks, picture agencies, wire services or as free-lancers. They can be understood as travelling, professional and often professionally educated photographers, visiting a given location for the duration of a conflict (or a shorter period of time during a conflict) on assignment or as freelancers. Citizen photographers, on the other hand, are non-professional photographers who are familiar with the conditions they photograph qua citizen. They do not qualify as professional photographers and they are largely selfeducated. Reporting from their own neighbourhoods, they are intimately connected to the conflict zone. Their local identity increases their knowledge of the conflict and its underlying dynamics and may facilitate access to sources unavailable to outsiders. They publish their work mainly on-line through social media (Allan 2013). ${ }^{5}$

Professional photographers and citizen photographers often operate on the same turf, competing for the same outlets and audiences. Their relationship, hardly surprisingly, is a complicated, often competitive one, dominated to some extent, it seems, by mutual suspicion and mistrust. Claiming superiority resulting from professional education appears increasingly irrelevant due to technical improvements of photographic devices enabling even untrained people occasionally to produce highquality images; these images may then be published in newspapers - formerly the domain of the professionals. What is more, using smart phones may prove to be an advantage for citizen photographers in the sense that their photographic activities are not as obvious as are those performed

\footnotetext{
5 There are also independent documentary photographers who are neither professional photojournalists nor citizen photographers as defined above, "documentary photographers who have the fortitude, desire, and resources to work independently" (Ritchin 2013, 118). Discussion of this group of photographers is excluded from what follows. Due to their non-presence on location during violent conflict, art photographers and aftermath photographers are not discussed here, either (on aftermath photography, see D uganne 2007; Lisle 2011; Baker and Mavlian 2014).
} 
by their professional colleagues using professional equipment, thus arguably increasing the authenticity of both their subjects' behaviour in front of the camera and the resulting images. However, while professional photographers have, in principle, the possibility of leaving when a situation becomes too dangerous, citizen photographers do not normally have this option; and they do not enjoy the protection, limited as it may be, professional photojournalists enjoy.

Citizen photographers are personally affected by the conflict they photograph and its outcome. Rather than being neutral, third party observers, they can be expected to have a political agenda. (Indeed, citizen photographers may criticize the alleged neutrality of their professional colleagues, arguing that in armed conflict photographers have to take sides. Such argument would be in accordance with a part of the photojournalistic tradition; see below.) Citizen photographers may be interested in documenting a conflict but they may also be interested in visualizing their politics including, if deemed necessary, appeals to intervention from the outside. Professional photographers, on the other hand, may restrain from visualizing their own politics while documenting a conflict as objectively as possible - within the limits of the medium. In accordance with standard photojournalistic operating procedures, they may also restrain from manipulating or altering their photographs in order to advance their politics. Fred Ritchin summarizes the above positions by writing that 'the work of citizen journalists,' while offering new perspectives, 'can also be skewed by their own agendas, privileging advocacy over witnessing, often lacking a broader perspective" (Ritchin 2013, 118). Citizen photographers, then, are too present, too involved in the conditions they depict to merely document them. Ritchin's assessment implies that professional photographers do not have their own agendas, privilege witnessing over advocacy and have a broader perspective, all of which is far from obvious.

Surely, professional photographers find themselves under pressure from non-professional photographers who seem to be everywhere, offering low-cost alternatives to the work produced by professionals and disseminating their work in real-time through the Internet and thus often extremely fast (Jeffries 2013). D igitization is indeed the condition of possibility for the emergence of citizen photography as a mass phenomenon, undermining the identity and income opportunities of professionals. In order to establish a difference between the images produced by citizen photographers and the work produced by professional photographers that may look strikingly similar, professionals insist on both verifiability by means of established forms of crosschecking and ethical standards to which they adhere. Crosschecking costs time - time that often seems to be lacking in the frenzy of breaking news and 24-hour news channels. It is nevertheless indispensable because it is seen to guarantee the credibility and accurateness of any published professional photograph. In a long interview with Errol Morris, photographer Ben Curtis explains: 
As an editor, if you have any suspicions at all about an image, you call up the photographer and say, 'Okay, what happened? Where were you?' Y ou interrogate the people in the field. As a photographer, when I write my captions, I'm very meticulous and methodical, and I go through and check them before I send them, and I have to establish to my own satisfaction that everything I've said in the caption is true, and that I can stand by it because I've witnessed it myself with my own eyes, or I've questioned the people in the field and I'm confident that I can stand by that information (as quoted in Morris 2014, 190; italics added).

As regards ethical standards to which professional journalists adhere, ${ }^{6}$ acclaimed photographer Louie Palu (2017, 59), while acknowledging that amateur photographers "can sometimes take images that are inarguably newsworthy," articulates his uneasiness with the term "citizen journalist" when applied to such photographers. Palu $(2017,59)$ explains that he, as "a working journalist," has "always followed a code of ethics that, among other things, calls for independence and impartiality. Professional journalists may fall short of ethical aspirations, but they consider the impact of their images in a way that amateurs might not."

In sum, citizen photographers expand our understanding of the events depicted. They may take pictures of things and people professional photographers miss or find irrelevant. They may photograph things that professional photographers also photograph but they may do so differently. Citizen photographers are "agents of their own image" (Möller 2012, 66) rather than subjects of the photography of others and their work contributes to the democratization of image making. Citizen photographers are (seemingly) ubiquitous, often following the traditional photojournalistic credo that proximity to action is required to take 'great' pictures. However, their work cannot easily be verified independently (Allan 2013, 193, 2014, 177) and they are under suspicion of not constantly, if at all, observing ethical standards professional photographers are supposed to adhere to. Furthermore, being first citizens then photographers, citizen photographers, being a part of the conflict they photograph, might be accused of producing images that cannot be relied upon as accurate, truthful or objective?

Before zooming in on the photographer as a witness, it is necessary to establish what, according to photographic discourses, qualifies as proper photojournalistic operating procedures. This step is necessary, not only because the myth of photojournalism defines proper photojournalistic behaviour but also because it serves as the standard against which the work of citizen photographers is often evaluated.

\footnotetext{
${ }^{6}$ Respecting ethical standards would seem to be particularly important with regard to photographic representations of violence. The relevant literature is substantial; see, for example, Sontag (2003), Reinhardt, Edwards, and Duganne (2007), Butler (2010), and G rønstad and Gustafsson (2012).

${ }^{7}$ Such accusations can be effective even in the absence of empirical evidence. Just as the credibility of photojournalistic images is to some extent a discursive construction, doubts about the credibility of citizen photography can be talked and written into existence.
} 


\section{Standard operating procedures}

"Let him who wishes to know what war is look at this series of illustrations," O liver Wendell Holmes wrote in 1863, commenting on Matthew Brady's A merican Civil War photography (Holmes 1863, 11). According to Holmes, this photography is not what war looks like; it is not what war looks like when photographed, either. It is, essentially, what war is: this is war. THIS IS WAR! was the title of a D ecember 3, 1938 Picture Post story about the battle of Rio Segre during the Spanish Civil War which featured the photography of Robert Capa, the paradigmatic war photographer, whose work still sets the standard for war photography. TH IS IS W A R! is also the title of Richard Whelan's Capa biography (Whelan 2007). To be sure, there are substantial differences between Brady's approach and Capa's. For example, Brady's photography was aftermath photography (mainly due to technical limitations rendering photography of moving subjects difficult) while Capa often, but not always, took pictures in close proximity to actual fighting. However, both approaches are said to show what war is and this supports the impression, cultivated also in numerous photography exhibitions, articles and book publications (Tucker and Michels with Zelt 2012), that photography is a privileged medium with regard to the representation of war and violent conflict.

The understanding of both war photography as a distinct photographic genre and the proper operating procedures for photojournalists cultivated in photography discourses since Capa's time are stable. They are indeed surprisingly stable given that concepts are contingent, changeable over time and across space. Concepts are "done" by people who "draw upon typified behavioural pattems to reproduce meaning in a particular setting or situation and, in the same act, to reaffirm or modify its sense" (McSweeney 1999, 165). As regards photojournalism, these patterns have been "done" in a remarkably stable manner for a remarkably long time, reaffirming rather than modifying them. As Ritchin (2013, 51) argues:

In the field of photojournalism the visual vocabulary has particularly stagnated, with national competitions and some of the well-meaning workshops establishing standards, mostly implicit, so that work by indigenous photographers comes to resemble imagery by foreign standard-bearers. Rather than discuss and value differences as providing new ideas for an expanding set of approaches, even in a weakened field a conformity reigns that constricts possibility. ${ }^{8}$

\footnotetext{
8 See, however, the World Press Photo Awards 2014 and 2015 for attempts to deviate from the tradition and establish a new visual vocabulary in photojournalism.
} 
This conformity pressure is not a coincidence. It reflects that photojournalism, for its acceptance as a privileged medium with regard to the representation of violence, depends on a specific form of discursive construction emphasizing at least four different elements: presence, non-partisanship, noninterference and proximity to action. Alternative forms of photographic expression did emerge but these forms find it difficult to get accepted as photojournalism; often they are discursively assigned to art rather than journalism, shown in museums and galleries to a limited audience. ${ }^{9}$ To be sure, the four essential patterns of behaviour characterizing the paradigmatic photojournalist tell us more about the myth of photojournalism and its discursive construction as they do about the practio of photojournalism which has always been much more variegated. However, I would like to suggest that the perception of photojournalistic images, including the meanings assigned to them, depends as much on the myth of photojournalism as it does on the practice of photojournalism: the myth conditions what we expect to see when we are told to see a photojournalistic, documentary image rather than, say, an art photograph. Without this myth, the whole idea of dooumentary photojournalism would collapse but also with it, the idea is not unproblematic.

O ne essential feature of the paradigmatic, ideal-typical photojournalist is presence on location. It is indeed customary to refer to photographers as witnesses (Sontag 2003, 80; Kennedy 2014, 46; Roberts 2014, 165). A photograph testifies to the photographer's presence on location: traditionally, "witness" references someone who is present on location when something happens to which he or she can testify from personal observation, ${ }^{10}$ and the act of testifying is dissociated from interpretation. Photographers collect 'data' and present it unaltered to the audience. The photographer, thus, is an eyewitness with a camera. This combination - eyewitness and camera - gives the photographer's testimony special credibility; the photograph offers proof of what happened and remedies, to some extent, the notorious unreliability of eyewitnesses (Levi 1989). Photojournalism, in its paradigmatic interpretation, is capable of supporting eyewitness narratives with visual evidence - evidence that what someone believes to have seen did actually take place precisely in the way he or she remembers it.

Witnessing and remembering are mostly local activities (Sontag 2003, 35) as long as both activities are connected with presence on location but photographic activity and evolving patterns of dissemination have contributed to the de-localization of acts of witnessing and remembering, thus introducing the distant witness as a mass phenomenon and necessitating a re-thinking of concepts of witnessing. Today most people with access to the Internet bear witness to conflicts, the existence of which would have been unfamiliar to them not too long ago. The distant witness is someone who is disconnected

\footnotetext{
9 See, for example, Richard Mosse's recent works on migration, Incoming and $H$ eat M aps, discussed on the arts pages of newspapers and shown in art centers and galleries.

10 The Shorter 0 x ford E nglish D ictionary on H istorical Prinaples, Vol. II, p. 2562.
} 
physically from the place where something takes place and who nevertheless through representation witnesses an event in parallel with or immediately following it. This figure is largely a creation of audiovisuality including radio, television, film and photography. The photographer, being an eyewitness with a camera himself or herself, is also an intermediary between the event personally witnessed and photographed and the audience. The audience, by looking at the resulting photographs, also becomes a witness - a different kind of witness but a witness all the same (see the discussion in Lindroos and Möller 2017, 33-55).

The second essential feature of the paradigmatic photographic witness is non-partisanship: photojournalists are neutral observers of, rather than parties to, conflict, interested in documenting the truth as it appears in front of their cameras. The truth may be hard to find (see Fig. 2) but it is the journalist's job to uncover it all the same because the alternative to the truth 'is a lie' (see Fig. 1).

\section{The truth is hard.}

The truth is hard to hear.

The truth is hard to accept.

The truth can't just be glossed over.

The truth must be pursued.

The truth is worth defending.

The truth requires tolking a stand.

The truth is more important now than ever.

\section{ฮึe Äew لِork Times}

Fig. 2: New York City, March 1, 2017 (photograph: author)

Non-partisanship does not rule out photographers' political engagement with the conflicts they photograph. However, photographers are nevertheless supposed to adhere to neutrality with regard to photographic documentation. In other words, they are supposed to refrain from tricking viewers into a specific interpretation of a given image and the conditions depicted in this image. Thus, photographers, regardless of their own politics, are expected to cover a given conflict visually neutrally, as it is or as it appears before the camera. However, insisting on non- partisanship is hard to reconcile with the history of photojournalism. For example, understanding Robert Capa's work as paradigmatic photojournalistic work in terms of non-partisanship - the disinterested third party - is complicated by the fact that this 
work was profoundly political. Indeed, as Brian Wallis $(2011,13)$ explains, visual journalism as understood and practiced by Capa and others meant "first, that the pictures themselves had to be wrenchingly dramatic and tell a human story." It meant, secondly, "that the photographs - and the photographer - had to be part of that story or action; and third[ly], that the photographer had to be engaged, had to have judged the political stakes in that story, and had to have taken sides."

D ocumentation, thus, joined hands with political and aesthetic judgements; taking sides is irreconcilable with neutrality and a third-party position.

The third essential feature of the ideal-typical construction of photojoumalism is non-interference in the conditions the photographers document. D orothea Lange, for example, was adamant; her first consideration with regard to photo-documentary practice was: "hands off! Whatever I photograph, I do not molest or tamper with or arrange" $(1982,46)$. Photojournalists do not technically alter the resulting images, either. Sometimes, however, they do. In early 2014, for example, the Associated Press (AP) cut its relationship with an award-winning photographer because he had digitally altered one of his photographs taken in the Syrian war by removing a colleague's video camera from the corner of the frame. This alteration was deemed unacceptable although, according to the AP's vice president and director of photography, it had "little news importance." Using software "to lighten or darken photos to replicate scenes as [photographers] witnessed them," is deemed acceptable ${ }^{11}$ while adding or removing things is not. However, Lange's insistence on non-interference appears problematic not only in light of the practice of some of the photographers she was associated with during her work for the Farm Security Administration ${ }^{12}$ but also in light of her second and third considerations - "a sense of place" and "a sense of time." Trying to picture whatever she photographs both "as part of its surroundings, as having roots" and "as having its position in the past or in the present" involves aesthetic judgments beyond mere documentation. Indeed, "the important thing is not what's photographed but how" (Lange 1982, 46, italics added). As Campbell (2015) notes, every form of photography is "a creative, interpretive process" and photojournalism is no exception.

While photographers do not often intervene physically in the conditions they bear witness to, the act of taking a picture is nevertheless a form of participation (Sontag 1977, 11-12). Presence on location equals interference. Graphic joumalist Joe Sacco $(2012,4)$ submits that journalists "are not flies on the wall that are neither seen nor heard." Sacco appears himself as "character" in his own stories; he is an observer but he also acknowledges both participating in that which he observes and being observed by

\footnotetext{
${ }^{11}$ See http:/ / www.theguardian.com/ media/ 2014/ jan/ 23/ photographer-dumped-altering-syria-image (accessed July 5, 2016). The issue here is not one of replicating scenes as the photographer witnessed them but rather one of replicating scenes as the photographer remembers having witnessed them and these two conditions are not identical as memories invariably change.

12 For an investigation of Arthur Rothstein's photography, see Morris (2014, 123-139).
} 
those whom he observes. Photojournalists are not flies on the wall, either. They therefore cannot not interfere in the conditions they document, as photographer Radhika Chalasani explains: "we're interfering with a situation by our very presence, and that automatically changes the dynamic." ${ }^{13}$ Being clearly identifiable as a photographer or appearing together with other photographers may protect an individual in situations of violent conflict. This is, for example, why photojoumalists when working in dangerous conditions tend to work in a group although, as Curtis (as quoted in Morris 2014, 302-303) explains, "[n]obody likes working in a group." Yet, should something happen, there may be someone to help you. Furthermore,

There's the feeling that if one or two photographers go up on their own, they could be mistaken for somebody carrying a gun or a rocket launcher or mistaken for someone in that area and attacked. There's a feeling that if a bunch of journalists turn up in five vehicles that are marked "TV" and the drones can clearly see that, well, there's a hope at least, that there's less of a chance of being attacked.

Thus, the presence of a photographer who can clearly be identified as a photographer "changes the dynamic" (Chalasani): it makes people respond and adapt their behavior to the photographer's presence by, for example, interacting with him or her. (It would be naive to assume that such interaction would necessarily result in less violent behaviour and less violent images.) Subjects of photography do things they would not do in the absence of photographers. They act. They perform. They collaborate with the photographer, using him or her as a vehicle with which to communicate their message. Photographers are well aware of this performance. They know that they may, in part, have created the situations they subsequently document. They witness a situation that is to some extent conditioned by their own presence - and this complicates the very idea of neutral photojournalistic documentation quite regardless of the question of intentionality.

Unless operating from a considerable distance, photojournalists cannot document a situation unaffected by their presence. (The omnipresence of photographic recording devices including surveillance cameras and drones furthermore suggests that people may constantly behave as if a photographer or a photographic device were present - and very often, he, she or it is present in fact.) Distance, however, is not only ethically problematic but also violates prox imity to adtion - the fourth element of the paradigmatic photojournalist. Yet presence changes the situation and this undermines the photographer's subject position of neutral third party. Neutrality implies non-involvement but presence renders non-involvement impossible; contemporaneity is the condition of possibility for photojournalistic witnessing but it makes such witnessing, understood as a neutral act of observation,

${ }_{13}$ See http:/ / www.guardian.co.uk/ media/ 2012/ jul/ 28/ gutted-photographers-who-didnt-help (accessed July 5, 2016). 
non-interference and non-participation, impossible. Thus, the four key elements of paradigmatic photojournalism as established and cultivated in photography discourses appear, at least in part, to be mutually exclusive. Although being very ambitious and hardly manageable during the work process, these elements might still serve as an ideal that photojournalists aspire for in order both to keep the standard of photojournalistic work as high as possible and to help differentiate this work from other forms of image production. It seems, then, that photojournalism cannot entirely abandon concepts of truth, faith in objectivity and declarations about reality, ideal-typical as such concepts and declarations might be, if it wants continually to be regarded as a privileged form of image production. Thus, once the myth of photojournalism is established in terms of neutral and accurate witnessing by disinterested observers, the work of citizen photographers can be dismissed with reference to their political agendas, which are said to render impossible adherence to proper photojournalistic operating procedures. Thus, while citizen photographers may be both on location when something happens and close to action and while they may merge with the surrounding environment easier than professional photojournalists (at least as long as they are not identified as image-producing individuals and especially if they operate cell phones), it is precisely with regard to non-partisanship that their status as photojournalists as defined above seems questionable. However, once the accuracy of the myth of photojournalism is called into question, photojournalism's ostensible superiority to citizen photography can be maintained only with reference to things outside the image: crosschecking and ethical standards. D oes this situation undermine the photographer's subject position as a witness? Or does it primarily require a more differentiated approach to the photographer as a witness? Thus, what kinds of witnesses are photographic witnesses?

\section{The photographic witness}

I want to think with Avishai Margalit, but in a different context, about what it means to be a witness. ${ }^{14}$ Thinking with Margalit helps us understand that, while documentation and evidence are a part of the

\footnotetext{
14 Margalit (2004) discusses acts of bearing witness in connection with the Holocaust and the Stalinist terror regime. Taking concepts out of context is always awkward - it always involves risks. However, there can be observed cross-fertilization and interactions among different memory discourses and also "dynamic transfers that take place between diverse places and times during the act of remembrance" (Rothberg 2009, 11). Bearing in mind that remembering is the condition for both bearing witness to an event after the event and sharing the act of witnessing with others, it makes sense analytically to decouple concepts of bearing witness from the context from which they originate and to think about the question of what they tell us about other contexts as well. When utilizing writings on the memory of the Holocaust, such procedure does not imply denial of the uniqueness of the Holocaust or an attempt at relativizing it. Accusations of "relativizing" the original event are never far away and this is, among other things, what I meant above when I wrote that the procedure suggested here is not without risks.
} 
stories citizen photographers show us, it is insufficient to evaluate citizen photography ex clusively in terms of documentation and evidence or, in Margalit's terminology, in terms of what it is like to be exposed to extraordinarily evil circumstances. Focusing on what it feels like to be exposed to such circumstances and thus emphasizing the affective dimension of being a witness helps us realize an important ingredient of citizen photography that is regularly obscured in discussions that focus on the extent to which citizen photographers do what professional photojournalists are supposed to do. It helps us acknowledge that the truth of the victim does not necessarily reflect empirically measurable and realistically photographable facts: it can be photographed in ways other than those privileged in photojournalism. Indeed, citizen photographers neither always nor necessarily do what photojournalists do. This is a merit, not a liability of citizen photography because it expands the established limits of representation. To be sure, subdividing the concept of bearing witness into only two categories politicl and moral - is radically simplistic. It should therefore be noted that a person can be one kind of witness in one situation and another kind of witness in another situation. It should also be noted that, while I link photojournalists to political witnesses and citizen photographers to moral witnesses, the diverse subject positions that every person carries with them make it impossible to understand photojournalists exclusively in terms of political witnesses and citizen photographers exclusively in terms of moral witnesses. And there may be witnesses who qualify neither as political nor as moral witnesses. Furthermore, fact and affect are not mutually exclusive and the work of many photojournalists does have a strong affective dimension.

I want to think with Margalit although he, in contrast to me, focuses on bearing witness to "suffering inflicted by an unmitigated evil regime" (Margalit 2004, 148). Photographers may bear witness to such a regime but they may also bear witness to lesser forms of violence. What, then, can we learn about the photographic witness by thinking about the witness in terms suggested by Margalit in the context of the Holocaust and the Stalinist terror regime? D oes such thinking expand our understanding of the multiple subject positions of photographers? What does Margalit have to say about the paradigmatic moral witness, the moral witness and the political witness, all of whom he treats as ideal-types, and how does what he has to say relate to the discussion of the photographic witness? Closest to a conventional understanding of the photographer as eyewitness would seem to be Margalit's definition of the political witness. Margalit emphasizes that the political witness, "by temperament and training," is especially suitable for uncovering both 'the structure of evil' and "the factual truth." Thus, the political witness may be very effective in "telling it like it was" (2004, 168, italics added). For the purpose of uncovering the factual truth, the political witness does not need to assume a first-person position but can "testify from a third-person perspective" $(2004,168)$, i.e. the political witness does not have to belong to the group of people targeted by the regime. The emphasis on training, the factual truth the political witness 
is interested in and the third-person perspective would seem to move the paradigmatic photojournalist, the professionally trained neutral third-party documentarian, rather close to the political witness. Margalit stresses that the political witness "believes that the incriminating evidence that she gathers is an instrument in the war effort" $(2004,167)$ and this would seem to coincide with the belief, or at least the hope, among photojournalists that their work may make others intervene in the conflict they document with other, non-photographic and politically more effective means. However, the paradigmatic photojournalist also seems to share some features with the moral witness. ${ }^{15}$

The subject positions of the moral witness, and especially those of the paradigmatic moral witness, are more ambitious. The paradigmatic moral witness, essentially, possesses "knowledge-by-acquaintance of suffering" (149). Such knowledge refers to both personal and actual experience of suffering; observation of such suffering is not sufficient for a person to qualify as a paradigmatic moral witness. This reservation implies that a photojournalist cannot be a paradigmatic moral witness unless she has herself personal and actual knowledge of suffering. However, an observer can be a moral witness if she is "at personal risk" (150) and a person is at risk if she is "belonging to the category of people toward whom the evil deeds are directed" (150). Thus, even without personal or actual experience of suffering, a person can be a moral witness on condition that she belongs to the same group as those who possess knowledge-by-acquaintance of suffering. A person is at risk also should she try "to document and record what happens for some future use" (150). Such a person qualifies as a moral witness only provided that the "testimonial mission has a moral purpose" (151) and that the documentarian takes risks: "To be a moral witness," Margalit posits, "is all about taking risks" (157). "Risk" thus appears to be a key word in his conceptualization: a moral witness has to be at risk or she has to take risks or both. Margalit emphasizes the "intrinsic value," the non-instrumentality, of the testimony of the moral witness, especially the paradigmatic moral witness (167). Such testimony is an end in itself, not a means to an end; it is articulated in order to appeal to a present or future audience. Thus, the moral witness just as the survivor (Wieviorka 2006) - needs an audience, present or future. Margalit $(2004,155)$ credits the moral witness with "a rather sober hope: that in another place or another time there exists, or will exist, a moral community that will listen to their testimony." Essentially, such testimony is not dependent on factual truth: "the moral witness is more valuable at telling it like it felt, telling what it was like to be subjected to such evil" (168, italics added). The political witness, on the other hand, is more valuable in telling it like it was. Thus, while a photojournalist may be stronger in showing it "like it was" rather than in showing it "like it felt," she shares with the moral witness some features: first, photojournalists take risks. Secondly, they document what happens for some future use. Thirdly, while

${ }^{15}$ Margalit acknowledges overlap between the moral and the political witness. 
they do not normally belong to the group of people originally targeted by the regime, they often become targets qua photojournalists. ${ }^{16}$ Fourthly, just like the moral witness, photojournalists hope for an audience: they hope that someone will regard their pictures and respond to them. Thus, the overlap between a moral and a political witness can be quite substantial. Finally, even if a given photojournalist does not qualify himself or herself as a moral witness, their work can be a connecting link between moral witnesses and the moral community, present or future

What, then, does Margalit himself have to say about journalists? His own reflections on journalists are brief and he does not comment on photojoumalists. He asks:

But then do foreign journalists whose professional business is to report the evil deeds of evil regimes, and who sometimes take tremendous risks while doing so, count as moral witnesses? The question is not whether hardboiled "war correspondents" want the title of moral witness added to their name. They may find it an insulting title, as if implying that they are going soft and becoming sentimental moralists. The question is for us, not for them. Do we want to ascribe to professional journalists the title of moral witnesses? The title should go to one whose testimonial mission has a moral purpose. Just reporting on evil because it is interesting and makes a good story, even if the reporting is risky, is to report with no moral purpose (2004, 150-151).

Thus, to be a moral witness is not only about taking risks. It is also, and crucially, about having a moral purpose. Journalists, therefore, can be, but do not necessarily have to be, moral witnesses. If they are interested only in a good story, then they may fulfil an important political role but they would not qualify as moral witness and this is so regardless of the risks they may have taken. Margalit writes only about foreign, professional journalists. Writing before the emergence of citizen photography as a mass phenomenon, he does not discuss what kind of witness citizen photographers are. What, then, do we learn about citizen photographers when we think about them and their work in light of Margalit's conceptualization?

Citizen photographers are moral witnesses and even paradigmatic moral witnesses on condition that they fulfil the criteria established by Margalit. In this regard, they are not different from anyone else. In order to qualify as paradigmatic moral witness, they have to have knowledge-by-acquaintance of suffering. In order to qualify as moral witness, they have to belong to the group of people targeted by the regime, they have to take risks, or they have to document, with a moral purpose, what happens. At the same time, however, they are different from other moral witnesses because, being photographers disseminating their work (and doing so often online in real-time), they do not only bear witness to evil but they share the act of bearing witness immediately with others, appealing not to a future but to a

16 The Committee to Protect Journalists reports that 1238 journalists were killed since 1992. See https:/ / cpj.org (accessed May 27, 2017). 
present audience, making others bear witness too, albeit indirectly and mediated. 0 thers bear witness to the original event through the visual representation offered by citizen photographers but, as representation necessarily transforms (Strauss 2003, 10), the event they bear witness to cannot but be different from the event the photographers had themselves witnessed. In the process of bearing witness, events change.

That events change in the process of bearing witness may be problematic from the point of view of professional photojournalists and political witnesses who are interested in "telling it like it is." Is it also problematic from the point of view of citizen photographers who qualify as moral witnesses? This question, too, is for us, not for them. Citizen photographers may find it insulting to assume that they are not interested in telling it like it is but, rather, in telling it like it feels; they may insist that what they report is the factual truth. That may be so (within the limits of photography) but telling - and showing - what it feels like to be subjected to violence is an equally important part of being a witness, establishing an affective relationship between the ones who suffer and their audiences. Furthermore, showing what it feels like to be subjected to violence does not necessarily have to be identical with showing the factual truth (in which journalists would be interested). Rather than addressing such testimony in terms of lies (see Fig. 1), the issue would seem to be one of "personal, intimate truths" (Möller 2010, 130) - the truths of the victims. ${ }^{17}$ These truths can, of course, be analysed by journalists but regardless of the results of such analysis, they are likely to maintain (at least a part of) their emotional, affective power, especially if they were generated by citizen photographers who qualify as moral witnesses. As Ritchin $(2013,11)$ notes, "the very subjectivity of non-professionals ... can be reassuring." With regard to art, D ominick LaCapra $(2004,43)$ notes "other than narrowly documentary or informational" ways of bearing witness and Jill Bennett, in her work on the "affective operations of art" in the context of traumatic memories, emphasizes that the "politics of testimony ... requires of art not a faithful translation of testimony; rather, it calls upon art to exploit its own unique capacities to contribute actively to this politics" (2005, 3; italics in original). Likewise, photography is called upon to contribute to a politics of testimony by exploiting its own unique capacities beyond documentation and information. According to Thompson, for example, photography is "uniquely fitted to mediate" what the photographer calls "the pathetic understanding of an other" (2013, 78; italics in original), with "pathetic" referencing pathema, i.e., "an experience passively received: acquiescence to what is seen" (14). Such mediation is not dependent on objectivity. Debates limited to truth and objectivity tend to

\footnotetext{
17 In a similar fashion, Thompson (2003, 17-48) follows the trajectory of photographic discourses from verisimilitude to correspondence between the picture and the experience of the artist, and from this correspondence to the truth of the subject depicted (see also Roberts 2014, 150). The truth of the victim is a kind of truth even if it cannot be corroborated by factual evidence.
} 
obscure both "the affective operations of art" (Bennett 2005, 3) and the affective operations of photography.

\section{Conclusion}

Both professional photojournalists and citizen photographers visualize an opinion, a subjective point of view reflecting numerous choices. If we differentiate the work of professional photographers from the work of citizen photographers arguing that the work of the professionals is more credible, more reliable and more objective than the work of the non-professionals, then this differentiation is primarily indicative of both the power of the myth of photojournalism and the biases we are socialized into believing. It is unfair on both citizen photographers and professional photojournalists: photojournalists are citizens, too. Furthermore, photography is always "highly interpretive, ambiguous, culturally specific, and heavily dependent upon contextualization by text and layout" (Ritchin 1999, 72) and this is true of the work of both photojournalists and citizen photographers. What we see is never the "real" world but the world as witnessed and photographed by a given photographer in a given situation, i.e., represented and, therefore, altered and transformed by the photographic act.

Safe arguments revolving around truth, objectivity and reality tend to "close down debate about what photojournalism and documentary photography are and do" (Campbell 2015). Applying the same arguments to citizen photography has the same effect. It regularly results in criticizing citizen photography for its alleged unreliability, insufficient regard for ethical standards and established photojournalistic procedures, and lack of verifiability. Furthermore, it means evaluating citizen photography in light of (idealized) operating procedures ostensibly governing photojournalism and, thus, thinking about it in terms other than its own. I suggested in this paper applying unsafe arguments to photography: arguments that are not yet established in photographic discourses to such an extent that they appear natural. Indeed, photography is, to a large extent, a discursive construction: it is how we think about it, how we conceptualize it, and what we make of it. O ne such unsafe argument is derived from Avishai Margalit's writings about political and moral witnesses. Essentially, a political witness bears witness to what it is to be exposed to extraordinary circumstances while a moral witness bears witness to what it feels like to be exposed to such circumstances. Thinking about photojournalists and citizen photographers in these terms (but also paying attention to the caveats sketched above) helps uncover dimensions of photographic work that tend to be obscured in more established discursive approaches. "The beauty of photography," Campbell (2015) writes, "is that it is a creative, interpretive process in which something about the world is visualized." This assessment applies to all forms of 
photographic work. Different photographic approaches testify to different "somethings." They witness - and make viewers witness - the world differently.

\section{References}

Allan, Stuart. 2013. "Blurring Boundaries: Professional and Citizen Photojournalism in a Digital Age." In The Photographic Image in D igital C ulture. Second E dition, edited by Martin Lister, 183-200. London: Routledge.

Allan, Stuart. 2014. "Photo-Reportage of the Libyan Conflict." In The V iolenœ of the Image: Photography and International Conflict, edited by Liam Kennedy and Caitlin Patrick, 167-192. London: I.B. Tauris.

Allan, Stuart, ed. forthcoming. Photojournalism and Citizen Journalism: C o-operation, Collaboration and Connectivity. London: Routledge.

Baker, Simon, and Shoair Mavlian, eds. 2014. C onflict - Time - Photography. London: Tate Publishing.

Bennett, Jill. 2005. E mpathic V ision: A ffect, Trauma, and C ontemporary A rt. Stanford: Stanford University Press.

Butler, Judith. 2010. Frames of W ar: W hen Is L ife G rievable? London: Verso.

Campbell, David. 2015. "Securing the Credibility of Photojournalism: New Rules from World Press Photo." L ens Culture. Accessed March 27, 2017. https:/ / www.lensculture.com/ articles/ david-campbell-securing-thecredibility-of-photojournalism-new-rules-from-world-pressphoto?utm_source $=$ General + List\&utm_campaign $=5 \mathrm{c} 01 \mathrm{~d} 54801$ -

$12 \% 2 F 3 \% 2 F 15+N e w s l e t t e r \& u t m$ medium=email\&utm_term=0 f1724e682d-5c01d54801-67613425.

Duganne, Erina. 2007. "Photography after the Fact." In Beautiful Suffering: Photography and the T raffic in Pain, edited by Mark Reinhardt, Holly Edwards, and Erina Duganne, 57-74. Williamsburg: Williams College Museum of Art/ Chicago: University of Chicago Press.

Grønstad, A sbjøm, and Henrik Gustafsson, eds. 2012. E thics and Images of Pain. New York: Routledge.

Gursel, Zeynep D evrim. 2016. Image Brok ers: V isualizing W orld N ews in the A ge of D igital C iraulation. Berkeley: University of Califormia Press.

Holmes, Oliver Wendell. 1863. "D oings of the Sunbeam." A tlantic M onthly: a M agazine of Literature, A rt, and Politics XII (LXIX): 1-15.

Jeffries, Stuart. 2013. "The D eath of Photography: Are Camera Phones D estroying an Artform?” The G uardian, D ecember 13, 2013. Accessed July 5, 2016. http:/ / www.theguardian.com/ artanddesign/ 2013/ dec/ 13/ death-ofphotography-camera-phones.

Kennedy, Liam. 2014. " 'Follow the Americans': Philip Jones Griffiths's Vietnam War Trilogy.” In The V iolenœ of the Image: Photography and International C onflict, edited by Liam Kennedy and Caitlin Patrick, 34-59. London: I.B. Tauris.

LaCapra, D ominick. 2004. H istory in Transit: E x perienœ, Identity, Critical Theory. Ithaca: Cornell University Press.

Lange, D orothea. 1982. Photographs of a L ifetime. W ith an essay by Robert C oles. A fterword by Therese H eyman. New York: Aperture.

Levi, Primo. 1989. The D rowned and the Saved. Translated by Raymond Rosenthal. New Y ork: Vintage. 
Lindroos, Kia, and Frank Möller. 2017. "Witnessing in Contemporary Art and Politics." In A rt as a Political W itness, edited by Kia Lindroos and Frank Möller, 33-55. O pladen: Barbara Budrich Publishers.

Lisle, D ebbie. 2011. "The Surprising D etritus of Leisure: Encountering the Late Photography of War." E nvironment and Planning D : Society and Spaœ 29 (5): 873-890.

Margalit, Avishai. 2004. The E thics of M emory. Cambridge, MA: Harvard University Press.

McSweeney, Bill. 1999. Security, Identity and Interests: A Sociology of International Relations. Cambridge: Cambridge University Press.

Möller, Frank. 2010. "Rwanda Revisualized: Genocide, Photography, and the Era of the Witness." A lternatives: G lobal L ocal, Political 35 (2): 113-136.

Möller, Frank. 2012. "Celebration and Concern: Digitization, Camera Phones and the Citizen-Photographer." In Images in M obile Communication: $\mathrm{N}$ ew C ontent, $\mathrm{N}$ ew U ses, $\mathrm{N}$ ew Perspectives, edited by Corinne Martin and Thilo von Pape, 57-78. Wiesbaden: Verlag für Sozialwisenschaften.

Möller, Frank. 2017. "The Violence of Witnessing." In A rt as a Political W itness, edited by Kia Lindroos and Frank Möller, 219-239. O pladen: Barbara Budrich Publishers.

Morris, Errol. 2014. B lieving Is Seeing (O bservations on the M ysteries of Photography). New Y ork: Penguin.

Palu, Louie. 2017. "Image Control in the Age of Terror." In A rt as a Politicl Witness, edited by Kia Lindroos and Frank Möller, 57-64. O pladen: Barbara Budrich Publishers.

Patrick, Caitlin. 2014. "Ruins and Traces: Exhibiting Conflict in Guy Tillim's L eopold and M obuto." In TheV iolenœ of the Image. Photography and International C onflict, edited by Liam Kennedy and Caitlin Patrick, 235-255. London: I.B. Tauris.

Rancière, Jacques. 2009. The E mancipated Spectator. Translated by Gregory Elliott. London: Verso.

Reinhardt, Mark, Holly Edwards, and E rina Duganne, eds. 2007. Beautiful Suffering: Photography and the Traffic in Pain. Williamsburg: Williams College Museum of Art/ Chicago: University of Chicago Press.

Ritchin, Fred. 1999. In 0 ur 0 wn Image. New York: Aperture.

Ritchin, Fred. 2013. Bending the F rame. Photojournalism, D oaumentary, and the Citizen. New York: Aperture.

Roberts, John. 2014. Photography and Its V iolations. New Y ork: Columbia University Press.

Rosler, Martha. 2006. "in, around, and afterthoughts (on documentary photography." In 3 works, 61-93. Halifax: Press of the Nova Scotia College of Art and D esign.

Rothberg, Michael. 2009. M ultidirectional M emory: Remembering the H olocaust in the A ge of D eoolonization. Stanford: Stanford University Press.

Sacco, Joe. 2012. Journalism. London: Jonathan Cape.

Solomon-G odeau, Abigail. 2003. Photography at the D odks: E ssays on Photographic H istory, Institutions, and Practios. Foreword by L inda N ochlin. Minneapolis: University of Minnesota Press.

Sontag, Susan. 1979. 0n Photography. London: Penguin.

Sontag, Susan. 2003. Regarding the Pain of 0 thers. New Y ork: Farrar, Straus \& Giroux.

Strauss, D avid Levi. 2003. Between the E yes: E ssays on Photography and Politics. Introdudion by John Berger. New York: Aperture.

Thompson, Jerry L. 2003. Truth and Photography: N otes on L ooking and Photographing. Chicago: Ivan R. Dee. 
Thompson, Jerry L. 2013. Why Photography M atters. Cambridge, MA: MIT Press.

Tucker, Anne Wilkes and Will Michels with Natalie Zelt. 2012. W ar/ Photography: Images of A med C onflid and Its A ftermath. Houston: Museum of Fine Arts.

Wallis, Brian. 2011. "Recovering the Mexican Suitcase." In The M exican Suitase: The Redisovered Spanish Civil W ar N eyatives of Capa, Chim, and Taro. V olume 1: The H istory, edited by Cynthia Y oung, 13-17. New York: International Center of Photography/ G öttingen: Steidl.

Whelan, Richard. 2007. T H IS IS W A R! R obert C apa at W ork. New Y ork: International Center of Photography/ Göttingen: Steidl.

Wieviorka, Annette. 2006. The E ra of the W itness. Translated by Jared Stark. Ithaca: Comell University Press.

Wylie, Matthew. 2016. "Pull Away.” L ens C ulture. Accessed August 5.

https:/ / www.lensculture.com/ articles/ matthew-wylie-pull-

away?utm_source=G eneral+List\&utm_campaign=9fbfa8alb1-Newsletter-G eneral-7-28-

06\&utm_medium $=$ email\&utm_term $=0$ _ f1724e682d-9fbfa8alb1-67613425. 